\title{
Pliocene bear Ursus minimus Devèze de Chabriol et Bouillet, 1827 (Carnivora, Ursidae) in Russia and Kazakhstan
}

\author{
Gennady F. Baryshnikov \& Alexander V. Lavrov
}

\begin{abstract}
Mandibular fragments of the small Pliocene bear from Kosyakino in Northern Caucasus, Russia (MN15) and from Moiseevka in Irtysh River basin, Kazakhstan (MN14) revealed morphological similarity with the specimens of Ursus minimus. During the evolution of this species, the enlargement of molars and equalization of the $\mathrm{m} 1$ and $\mathrm{m} 2$ in length took place. Our study ascertained the presence of geographical variability of $U$. minimus in Eurasia in the Early Pliocene (U. m. boeckhi in Europe and U. $m$. ssp. in Kazakhstan) as well as in the Late Pliocene (U. m. minimus in Europe and U. m. yinanensis in China).
\end{abstract}

KEY WORDS: Ursus minimus, Ursidae, Pliocene, Caucasus, Kazakhstan.

Gennady F. Baryshnikov [G_Baryshnikov@mail.ru], Zoological Institute, Russian Academy of Sciences, Universitetskaya nab. 1, Saint Petersburg 199034, Russia; Alexander V. Lavrov [lavrov@paleo.ru], A. A. Borissiak Paleontological Institute, Russian Academy of Sciences, Profsoyuznaya ul. 123, Moscow 117647, Russia.

\section{Плиоценовый медведь Ursus minimus Devèze de Chabriol et Bouillet, 1827 (Carnivora, Ursidae) в России и Казахстане}

\section{Г.Ф. Барышников, А.В. Лавров}

\begin{abstract}
РЕЗЮМЕ. Фрагменты нижнечелюстных костей маленького плиоценового медведя из местонахождений Косякино на Северном Кавказе, Россия (MN15), и Моисеевка в бассейне реки Иртыш, Казахстан (MN14), обнаружили морфологическое сходство с образцами Ursus minimus. В процессе эволюции вида происходило увеличение размеров коренных зубов и имело место выравнивание длины $\mathrm{m} 1$ и $\mathrm{m} 2$. Наше исследование подтвердило существование у U. minimus в Евразии географической изменчивости как в раннем плиоцене (U. m. boeckhi in Europe and U. m. ssp. in Kazakhstan), так и в позднем плиоцене (U. m. minimus in Europe and U. m. yinanensis in China).
\end{abstract}

КЛЮЧЕВЫЕ СЛОВА: Ursus minimus, Ursidae, плиоцен, Кавказ, Казахстан.

\section{Introduction}

All recent bears of the Old World (except of bamboo bear, Ailuropoda melanoleuca (David, 1869) belong to the tribe Ursini Fischer, 1814 and derive (according to the data of mitochondrial phylogeny) from bears of the New World (tribe Arctotheriini F. Ameghino, 1903) at the beginning of the Late Miocene (Tortonian), near 12.86 Ma (Krause et al., 2008). The ancestor of ursine bears is regarded to be a member of the genus Ursavus Schlosser, 1899, presumably U. primaevus (Gaillard, 1899) (Baryshnikov, 2007).

Ursine bears radiation occurred at the time corresponding to the time period near the Miocene-Pliocene boundary (5.39 Ma by molecular data). The basal position by molecular phylogeny (see Krause et al., 2008) is occupied by the sloth bear, Melursus ursinus (Shaw, 1791). The appearance of the genus Ursus L., 1758, is referred to the beginning of the Pliocene $(5.05 \mathrm{Ma})$. The time of divergence of the two species of black bears (Ursus thibetanus G. Cuvier, 1823 and U. americanus Pallas, 1780) was determinate as $4.08 \mathrm{Ma}$.
The earliest member of the genus Ursus is regarded to be the fossil bear $U$. minimus Devèze de Chabriol et Bouillet, 1827 (=U. arvernensis Croizet et Jobert, 1828), which presumably was the ancestral taxon for black bears, cave bears, and brown bears of Eurasia and North America (Baryshnikov, 2007). The greatest similarity of $U$. minimus to the Asian black bear (U. thibetanus) is expressed in their dental morphology. Hence, the findings of the teeth of Pliocene ursids in Europe are often determinated as $U$. ex gr. minimus-thibetanus (Wagner, 2010).

$U$. minimus is represented by cranial fragments, lower jaws, isolated teeth and some bones of postcranial skeleton (Croizet \& Jobert, 1828; Depéret, 1890; Maier von Mayerfels, 1929; Roshchin, 1956; Ryziewicz, 1969, Berzi, 1966; Jánossy, 1978; etc.). However, its taxonomic position remains questionable. Some researchers divide $U$. minimus for several taxa: $U$. boeckhi Schlosser, 1899 (Early Pliocene, Europe), U. minimus s.str. (Late Pliocene, Europe), U. yinanensis Li, 1993 (Late Pliocene, China) and U. abstrusus Bjork, 1970 (Early Pliocene, North America) (Li, 1993; Tedford \& Harington, 2003; Wagner, 2010). The others 


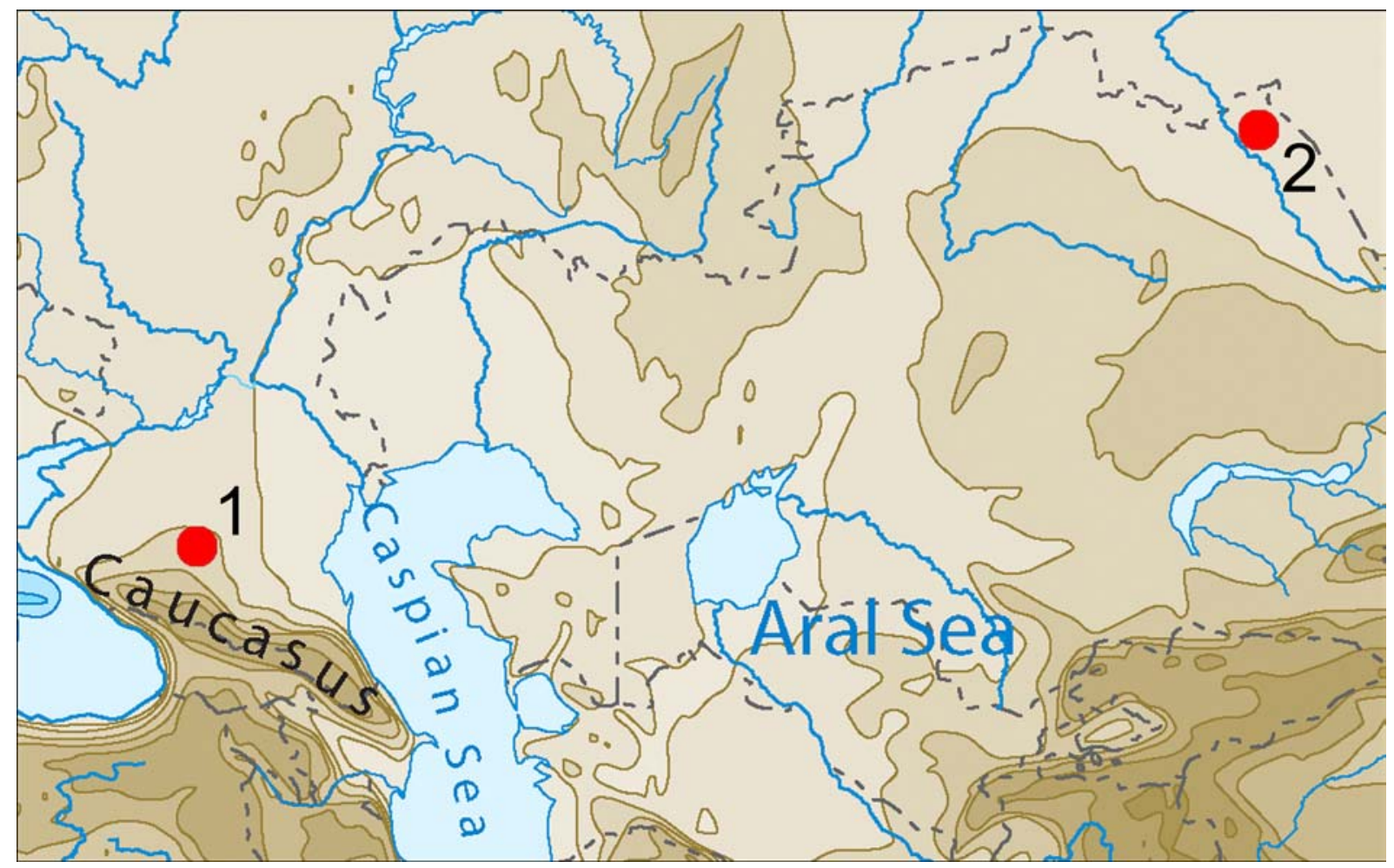

Figure 1. The geographic positions of the localities of Ursus minimus considered in the paper.

1 - Kosyakino, 2 - Moiseevka.

consider these taxa to be subspecies of the single polytypical species of $U$. minimus, which formed the PanHolarctic distribution (Baryshnikov, 2007). Some paleontologists consider that all bear fossils from Europe of this age belong to a single species $-U$. minimus (Morlo \& Kundrát, 2001). Moreover, the idea has been put forward on separating of black bears in two genera: Protarctos Kretzoi, 1945 (P. boeckhi, MN14; P. ruscinensis Depéret, 1890, MN15; P. yinanensis, MN1617), and Euarctos Gray, 1864 (E. pyrenaicus Depéret, 1892, MN15; E. minimus, MN16-17; and recent species: E. thibetanus and American baribal E. americanus), was suggested by Qui et al. (2009). Thus the species $U$. thibetanus and $U$. americanus are excluded from the genus Ursus. However, this opinion is based mainly on the morphology of one tooth $\mathrm{m} 1$ only. This point of view is disputable by the reasons of the significant variability of dental characters in bears as well as molecular studies supporting the monophyly of the genus Ursus (Pagés et al., 2008).

European findings of U. minimus in the Early Ruscinian (MN14) are known from Alcoy in Spain, Montpellier in France (MN14a), Kuchurganian beds (Trudomirovka) in Ukraine, Baraolt-Căpeni in Romania (=Barót-Köpecz in Hungary), and Dorkovo in Bulgaria (Schlosser, 1899; Maier von Mayerfels, 1929; Korotkevich, 1967; Dubrovo \& Kapelist, 1979; Spassov, 2003; Montoya et al., 2006; Wagner, 2006). In the late Ruscinian and early Villanyian localities, the species was recorded in Perpignan, France (MN15a), Layna,
Spain and Węże 1, Poland (MN 15b), Wölfersheim, Germany (MN15b), Odessa Catacombs, Ukraine (MN 15/16), Gaville, Triversa, Arondelli, Ponzano, Italy (MN16), Les Etouaires, France (MN16b), Včeláre 2, Slovakia (probably MN16), and Osztramos 7, Hungary (MN16b) (Roshchin, 1956; Berzi, 1966; Ryziewicz, 1969; Soria \& Morales, 1976; Jánossy, 1978; Mazza \& Rustioni, 1994; Alberdi et al., 1997; Morlo \& Kundrát, 2001; Sabol et al., 2008; Wagner, 2010; Wagner et al., 2012). Bears from aforementioned localities had been referred to different taxa, but later were assigned to $U$. minimus (synonymy see in Baryshnikov, 2007).

In Asia, U. minimus was discovered in Kvabebi, Georgia (MN16, Vekua, 1972), Kosyakino and Udunga (MN15) in Russia (Vereshchagin, 1959; Sotnikova \& Kalmykov, 1991; Baryshnikov, 2007; Sotnikova, 2008), as well as in Yushe (as Ursus sp.), Liang-ChiaHo [as U. cf. boeckhi; assigned to Helarctos sinomalayanus by Thenius (1947)] and Yinan (as U. yinanensis, MN16/17) in China (Zdansky, 1927; Teilhard de Chardin, 1940; Qiu et al., 2009). In North America, there are several findings (as U. abstrusus) in the Early Blancanian sites (Hagerman, White Bluffs, Buckeye Creek) and Late Blancanian sites (Cita Canyon) in the USA (Kurtén \& Andersen, 1980; Kelly, 1994) and in Canadian Arctic (Elsmere Island; Tedford \& Harington, 2003).

Though the remains of Ursus minimus are known from numerous localities, the findings of this species are rather rare. The evolutionary changes of teeth and 


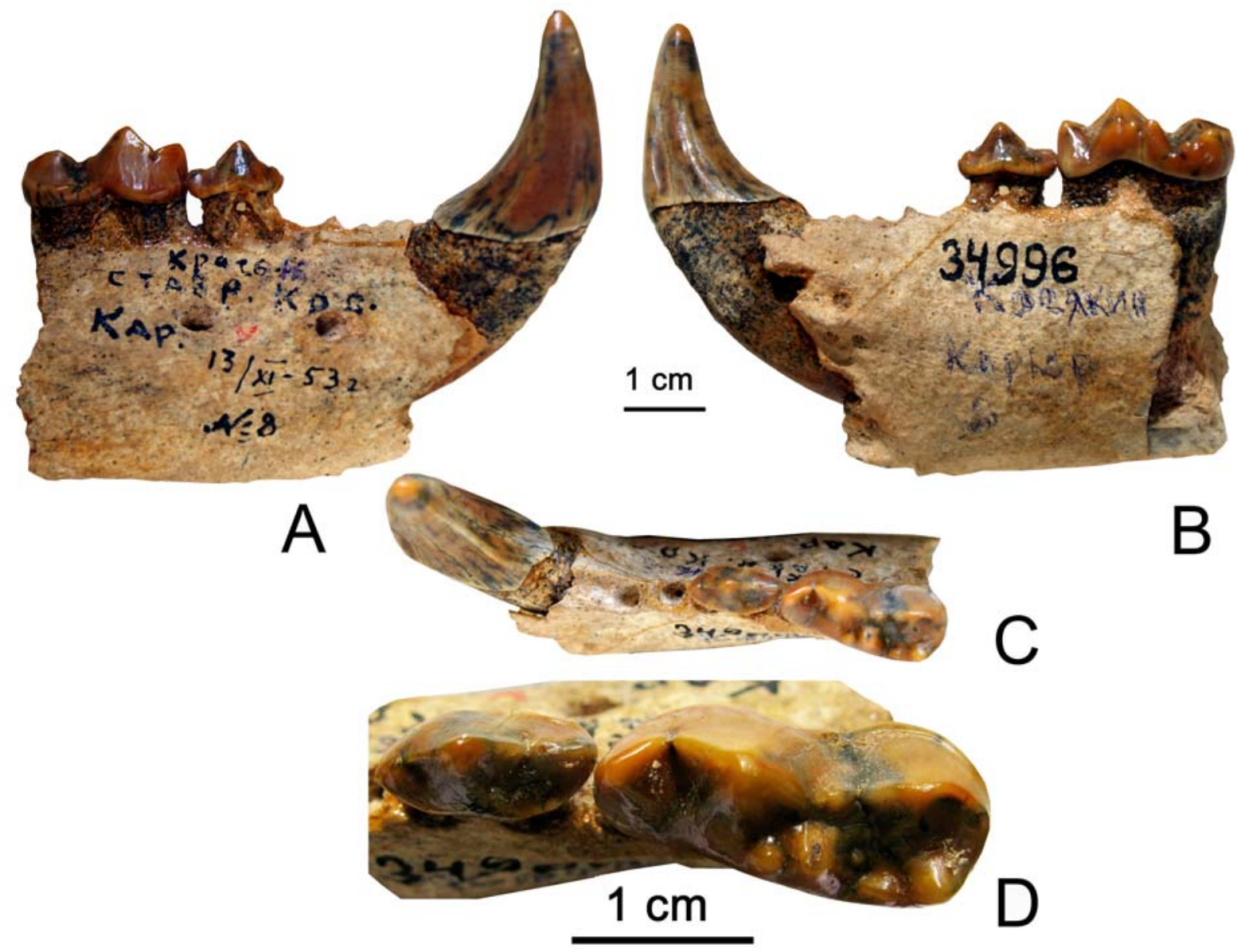

Figure 2. The fragment of the right mandibular ramus of Ursus minimus from Kosyakino, Northern Caucasus (ZIN 34996); labial (A), lingual (B) and occlusal (C, D) views.

skull characters of this species, as well as its variability, remain unclear. Therefore, the prior attention was given to the complete description of the material from the territories of Russia and Kazakhstan. This material makes possible estimating of morphological changes throughout all specific range of $U$. minimus from West European to Chinese localities.

In this publication we describe the morphological features of the lower jaws from Northern Caucasus (Kosyakino) and from the northern part of Kazakhstan (Moiseevka) for the first time (Fig. 1). Examined material is stored in Zoological Institute, Russian Academy of Sciences in St. Petersburg (ZIN) and in A.A. Borissiak Paleontological Institute, Russian Academy of Sciences in Moscow (PIN). For comparative analysis, we used the collections of several European depositories (see Institutional abbreviations).

In the definition of the mammal ages and their correlation with the chronostratigraphical scale as well as the MN-zones we follow Mein (1990), Fejfar \& Heinrich (1990), Fejfar et al. (1998), and Wagner et al. (2012).

Institutional abbreviations. CBUL - Claude Bernard University Lyon 1, Villerbann, France; IGF Museo di Storia Naturale, Sezione Geologia e Paleon- tologia, Università di Firenze, Italy; ISEA — Institute of Systematics and Evolution of Animals, Krakow, Poland; SNMB - Slovak National Museum, Bratislava, Slovakia; NHMN - Muséum National d'Histoire Naturelle, Paris, France; PIN - A. A. Borissiak Paleontological Institute, Russian Academy of Sciences, Moscow, Russia; ZIN - Zoological Institute of the Russian Academy of Sciences, Saint Petersburg, Russia.

\section{Localities and material}

Kosyakino. This locality (sand quarry) is situated near Stavropol city in Northern Caucasus, Russia $\left(45^{\circ} 03^{\prime} \mathrm{N}, 41^{\circ} 57^{\prime} \mathrm{E}\right)$. The mammalian fossils were located in the sandy alluvial deposits and were redeposited by the ancient river (Vereshchagin, 1959).

Originally the list of mammalian taxa from this locality included: Ursus cf. arvernensis Croiz. et Job., Dinocyon cf. thenardi Jourd., Felis cf. issiodorensis Croiz. et Job., Ochotona cf. antiqua Pidopl., Lepus sp., Amblicastor caucasicus Argirop., Steneofiber sp., Anancus arvernensis Aymard, Dinotherium sp., Hipparion gracile Kaup, Tapirus cf. arvernensis Croiz. et Job., 
Dicerorhinus orientalis Schlosser, Aceratotherium cf. incisivum Kaup, Propotamochoerus provincialis Gervais, Procapreolus sp., Pliocervus sp., Pseudalces sp., Gazella sp., etc. (Argiropulo, 1939, 1940; Beliaeva, 1940, 1944; Vereshchagin, 1959).

Later some of these taxa were redefined. The beaver Amblicastor caucasicus was determinated as porcupine Hystrix caucasicus (Lopatin et al., 2003); hemicyonid Dinocyon cf. thenardi as ursid Agriotherium sivalense minutum Gerv. (Baryshnikov, 2007). The list of the lagomorph species was also modified: Prolagus caucasicus Averianov et Tesakov, Ochotona cf. antiqua, Hypolagus cf. igromovi Gureev (Averianov \& Tesakov, 1998).

The geological age of Kosyakino is determinated as Early Ruscinian (MN14) based on lagomorphs (Averianov \& Tesakov, 1998) or as Late Ruscinian (MN15) according to carnivores' data (Vislobokova et al., 2001).

Ursid findings from Kosyakino were represented by two right mandible fragments. The specimen ZIN 34996 (Fig. 2) includes the lower canine, alveoli p1-p3 and also cheek teeth $\mathrm{p} 4$ and $\mathrm{m} 1$. The color of bone is light gray. Tooth enamel is light brown, with indistinct dark spots (collected by N.K. Vereshchagin in September 13, 1953). The specimen PIN No.225/253 (Fig. 3) includes the fragment of the lower canine, alveoli p1p3 and molars $\mathrm{m} 1-\mathrm{m} 2$. The bone is dense; its color is beige turning to light brown. Tooth enamel is colored as that of the specimen ZIN 34996. The bone mineralization is high. Vereshchagin (1959: Fig. 24, 1, 3) identified the lower jaw fragments from Kosyakino as Ursus cf. arvernensis but not described it. This paper includes illustrations of both lower jaw fragments of ursids from Kosyakino. Vereshchagin (1959) reported that 12 ursid bones totally were collected in the locality.

Moiseevka. The locality is situated at the right bank of the Irtysh River near Moiseevka village in Zhelezinsky District of Pavlodar Region, Kazakhstan $\left(53^{\circ} 27^{\prime} \mathrm{N}\right.$, $\left.75^{\circ} 28^{\prime} \mathrm{E}\right)$. The age of the finding is not precise, but Pliocene age is mentioned in the museum label.

The member of green clay is located at the left bank of the Irtysh River; these clays were dated as OligoceneMiddle Miocene. The same type of deposits is present at the right bank of the Irtysh River. This member is overlain by Late Miocene and Pliocene deposits (Nikiforova, 1953). Near from the village Moiseevka the member sandy (psammitic) and marlaceous clays was established as Moissevskaya svita, in which were found fossils of Equus stenonis Cocchi fossils (Kostenko, 1963). Zinova (1982) included Moissevskaya svita as a member within the compound of Podpusk-Lebiazchinskaya svita characterized by presence of Archidiskodon gromovi Garutt et Alex., Equus stenonis Cocchi, Elasmotherium sp., Gazella cf. sinensis Teih. et Piv., "Vulpes" odessanus Odinz. (=Eocyon odessanus, see Sotnikova \& Rock, 2010). E. Vangengeim (1977) considered that Podpusk-Lebiazchinskaya svita is analogous to Khaprovian age (Middle Villafranchian) of Eastern Europe. Vislobokova (1996) noted a presence of faunal horizons dated earlier than Middle Villafranchian in the Moisevskaya svita.

Deposits of Novostanychnaya svita (stratum) in the neighborhood of the Moiseevka village are of Middle Pliocene age (Zinova, 1982: 44). In the deposits of this unit the bones of small mammals Desmanidae gen.?, Steneofiber, Prosiphneus, and Baranomys had been collected. According to the opinion of Zazhigin (1980) the presence of Baranomys and degree of evolutionary development of beaver Steneofiber teeth makes possible attribution of Novostanychnaya svita to the horizon directly below the Akchaghylian beds. It's very likely that described lower jaw originates from these deposits. The deposits of this svita have been later attributed by $\mathrm{V}$. Zazhigin to the Late Miocene (MN13; Zykin et al., 2007). We determine the age of the ursid lower jaw from Moiseevka approximately as Early Pliocene (Early Ruscinian, MN14). This suggestion confirmed by the ursids morphological features described below.

Describing material from Kazakhstan presented by right ramus of the lower jaw with m1-m2 (PIN No.5332/ 1). It was found at the right bank of Irtysh River (outcrop number 130, specimen 207) in $2.5 \mathrm{~km}$ upstream from the Moiseevka village, Omsk Region (now Pavlodar region, Kazakhstan), collected by K. Nikiforova, Institute of Geological Sciences of Academy of Sciences of USSR, Moscow, September 7, 1948. The bone color is dark gray. Teeth are well preserved, the enamel is brown colored. The specimen was identified and labeled as Ursus arvernensis. This specimen was neither described nor figured earlier.

\section{Systematic Paleontology}

$$
\begin{gathered}
\text { Order Carnivora Bowdich, } 1821 \\
\text { Family Ursidae Fischer, } 1814 \\
\text { Genus Ursus Linnaeus, } 1758
\end{gathered}
$$

Ursus minimus Devèze de Chabriol et Bouillet, 1827

Description. Kosyakino (ZIN 34996, PIN No.225/ 253; Figs. 2, 3). The lower margin of the mandible is straight. The ramus is high; its height is decreasing forward. The mandibular symphysis is short, reaches the level of the premolar p3; a "chin" prominent at the ventro-caudal symphyseal edge is relatively small, but it's well expressed. The masseteric fossa is rather shallow and extends anteriorly to the level of the posterior margin of $\mathrm{m} 3$. Judging by the preserved part of the coronoid process, its anterior margin should be gradually upraised over the tooth row. There are two mental foramina: the anterior one is located at the level between $\mathrm{p} 2 / \mathrm{p} 3$ and posterior one is located directly below the contact between $\mathrm{p} 4$ and $\mathrm{m} 1$.

The axis of the tooth row is slightly curved in dorsal projection. There is an angle between the axes of premolar and molar rows. The masticatory surface of $\mathrm{m} 3$ is inclined anteriorly.

The shape of the canine is typical for bears. There are two carnassial ridges on the enamel surface (anteri- 


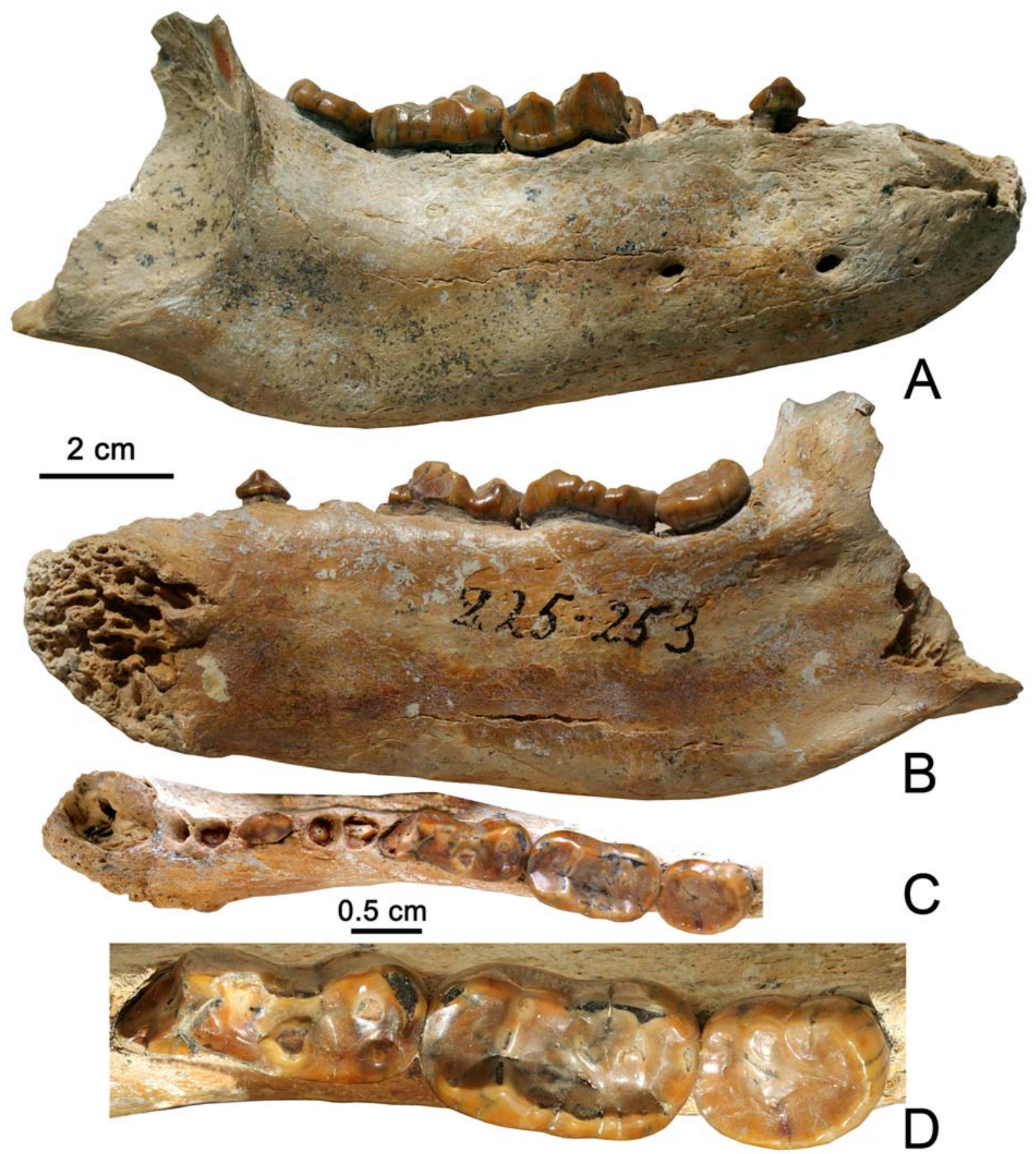

Figure 3. The right mandibular ramus of Ursus minimus from Kosyakino, Northern Caucasus (PIN No.225/253); labial (A), lingual (B) and occlusal (C, D) views.

or and posterior one). These ridges are slightly notched and run from the basis of the crown toward the canine apex. Also, a weakly developed ridge runs along the middle line of the lingual side of the crown. The tooth is somewhat turned along the longitudinal axis, so that the longitudinal axis is directed lingual from the row of cheek teeth.

The row of anterior premolars $\mathrm{p} 1-\mathrm{p} 3$ is crowded towards the canine. The postcanine diastema is absent.
The teeth $\mathrm{p} 1$ and $\mathrm{p} 2$ were single-rooted. The premolar p3 in ZIN 34996 is single-rooted as well. In the specimen PIN No.225/253 p3 is completely preserved, it's a small, single-cusped, and double-rooted tooth. In the recent species of the genus Ursus, the premolar p3 is single-rooted and frequently absent (in $U$. $\operatorname{arctos}$ L., $U$. maritimus Phipps).

The premolar $\mathrm{p} 4$ has two separated roots. There are two longitudinal enamel crests run nearly from basis of 
the crown to the apex of the main cusp. The anterior keel runs from a small cuspid near the crown margin. The posterior keel passes into elongated horizontal ridge. There is a slender buccal cingulid, which is better developed in the posterior portion of the tooth crown. The lingual cingulid is well expressed. It is looks like to a ridge in the posterior portion of the crown. It is upraised directly behind the base of the main cusp and forms separated cuspid (probably "metaconid").

The lower carnassial tooth $\mathrm{m} 1$ is comparatively small in contrast to other bears. The habitus of $\mathrm{m} 1$ is rather compact: its length is approximately twice the tooth width. The paraconid is short, shaped as a sharp tubercle; its anterior margin is parallel to the dorsoventral axis. The paraconid is approximately equal to metaconid in height. The protoconid is robust, high and has a trenchant anterior margin. The carnassials notch between paraconid and protoconid is rather shallow. The metaconid is massive, well separated from the protoconid. It is shifted posteriorly far from the caudal margin of the protoconid. In the specimen PIN No.225/ 253, the metaconid has a single apex (Fig. 3D), whereas the specimen ZIN 34996 has an accessorial cusp (premetaconid) in front of the metaconid (Fig. 2D), similar to recent black bears and brown bears. The talonid portion is comparatively short (the length being nearly equal to the width) and doesn't have the inner basin. The talonid is slightly wider than the trigonid, and there is a slightly expressed constriction between them. The greater part of the talonid is formed by the hypoconid which looks like a high three-edged cusp. The hypoconid possesses no separated inner structure in contrast to cave bears and brown bears. The entoconid is divided from the hypoconid. The entoconid has a single apex and is significantly smaller and lower than the hypoconid. There is a small entoconulid (ZIN 34996) in front of the entoconid. It is necessary to note that the entoconulid is absent on the specimen PIN No.225/ 253. The hypoconulid is absent in ZIN 34996. The posterior part of the crown has a distinct buccal cingulid. The lingual cingulid is absent.

The molar of $\mathrm{m} 2$ is slightly smaller in length than $\mathrm{m} 1$. The masticatory surface is subrectangular, without a distinct constriction. The trigonid and talonid are nearly equal in width. The anterior margin of the crown has an arched ridge. The paraconid is not developed. The protoconid has a single apex and it is rather low. The metaconid do not have an additional tubercles and it is noticeably higher than the protoconid. The inner ridges, running from the protoconid and metaconid merge together. These ridges divide anterior (the trigonid) and posterior (the talonid) parts of the interior region of the crown. The anterior part of the crown is cup-shaped and comparatively small. The posterior part is more extensive, spreading onto the talonid and displaying enamel folds. The hypoconid is single-cusped and it tends to form an inner lobe. The entoconid is ridge-shaped and exceeds hypoconid in height, being composed of two tubercles divided by a small cuspid. The distal ridge runs along the posterior margin of the crown, linking the hypoconid and entoconid; there are no clear traces of the hypoconulid. The buccal and lingual cingulids are absent.

The molar $\mathrm{m} 3$ is comparatively small and oviform. A slight separation of the talonid from the trigonid is traced on the buccal side of the tooth (this separation is especially well developed in the cave bears). The outer margin of the crown is upraised like a ridge with slightly expressed protoconid and hypoconid. The lingual surface of the tooth is somewhat wrinkled.

Moiseevka. The lower margin of the mandible fragment (PIN No.5332/1, Fig. 4) is nearly straight with a slight concavity below $\mathrm{ml}$; as a result, the height of the mandibular ramus decreases from the diaphysis towards the level of $\mathrm{m} 1$, increasing again at the level of $\mathrm{m} 2$. The symphysal part is large in regard to the mandible size; it extends backwards up to the level of $\mathrm{p} 2$. The "chin" (the ventral prominent) is absent. There are two approximated mental foramina distanced from each other at $6.3 \mathrm{~mm}$. The posterior opening is located below the alveolus of $\mathrm{p} 3$.

The postcanine diastema is absent. The canine is broken; its remaining part implies its size was somewhat smaller than that in ZIN 34996 (Kosyakino). The area between the canine and the molar $\mathrm{m} 1$ is occupied by three alveoli from anterior premolars $\mathrm{p} 1-\mathrm{p} 3$, which were single-rooted, as well as by two alveoli from the premolar $\mathrm{p} 4$.

The lower carnassial tooth is similar by proportions and shape to the specimen from ZIN 34996 (Kosyakino), being, however, somewhat smaller. The metaconid is single- cusped, less robust than that in the specimen from Kosyakino. The hypoconid is large; there is no accessorial tubercle between it and the protoconid. The entoconid is shaped like a ridge formed by two closely spaced cuspids (the first one being higher). The additional, tiny cuspid (entoconulid) is located in front of the entoconid, and closes the inner area of talonid from the lingual side.

The proportions and shape of the molar $\mathrm{m} 2$ are similar to those in PIN No.225/253 from Kosyakino, but, in contrast to the latter, the tooth is markedly shorter than $\mathrm{m} 1$. The metaconid is robust and singlecusped. The hypoconid is pronouncedly higher as compared to the entoconid (unlike in PIN No.225/253). The entoconid is ridge-like, and only two poorly expressed and widely spaced cuspids are present. The buccal cingulid is well developed.

Comparison. The comparison of a tooth sizes of $U$. minimus from various geological ages (horizons) shows that tooth sizes increased during the species evolution. The latest members of the species possess the largest

Figure 4. The fragment of right mandibular ramus of Ursus minimus (PIN No.5332/1) from Moiseevka, Kazakhstan; labial (A), lingual (B) and occlusal (C, D) views. 

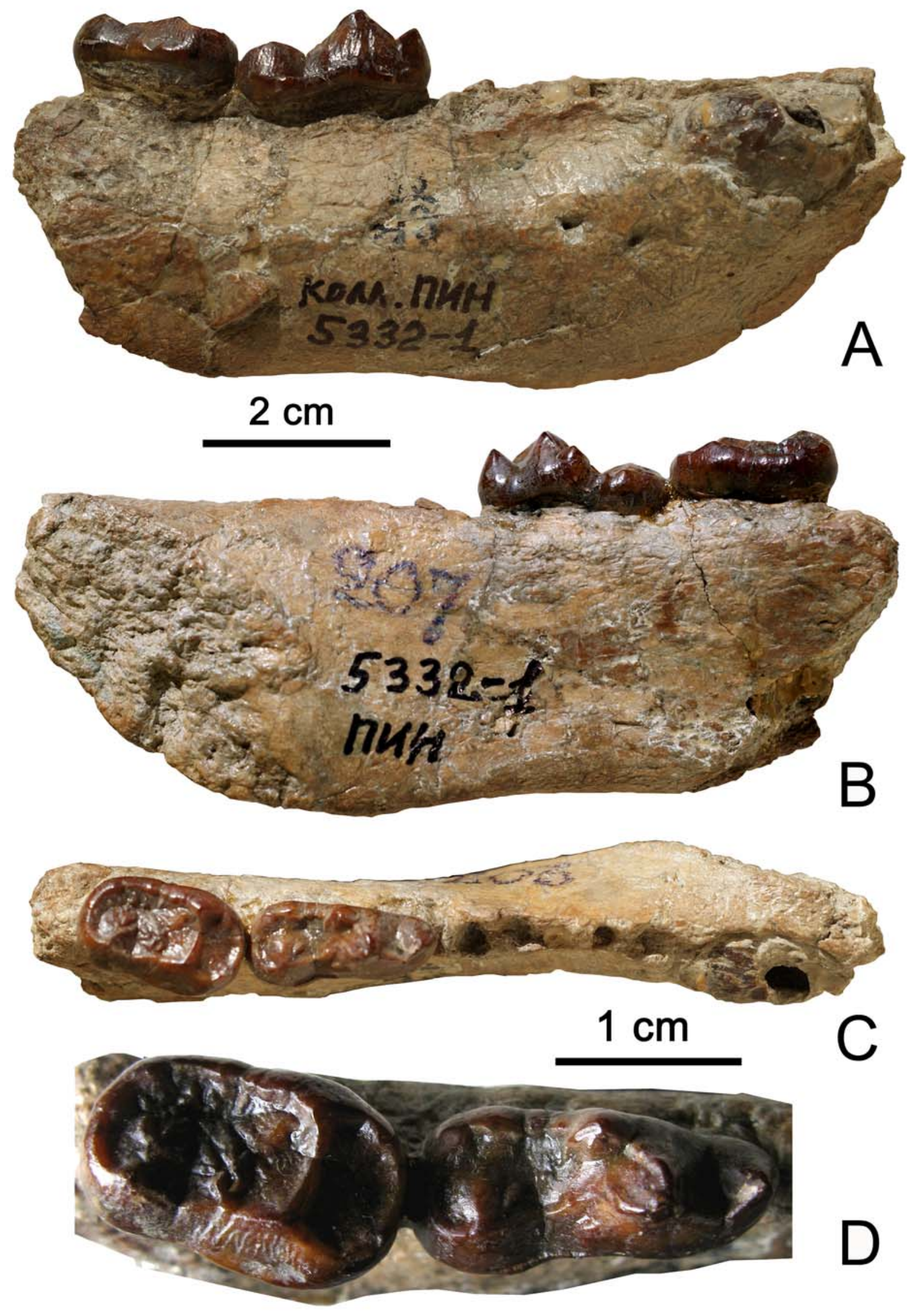

D 
Table 1. Sizes of the mandibles of Ursus minimus.

\begin{tabular}{|c|c|c|c|c|c|c|c|}
\hline \multirow{3}{*}{$\begin{array}{l}\text { Measurements, } \\
\mathrm{mm}\end{array}$} & \multicolumn{2}{|c|}{ U. m. boeckhi } & \multicolumn{5}{|c|}{ U. m. minimus } \\
\hline & \multirow{2}{*}{$\begin{array}{l}\text { Baraolt-Căpeni, } \\
\text { Romania } \\
\text { (=Baróth-Köpec, } \\
\text { Hungary) } \\
\text { CBUL 3302, cast }\end{array}$} & \multirow{2}{*}{$\begin{array}{l}\text { Moiseevka, } \\
\text { Kazakhstan } \\
\text { PIN 5332-1 }\end{array}$} & \multicolumn{2}{|c|}{$\begin{array}{c}\text { Kosyakino, } \\
\text { Russia }\end{array}$} & \multirow{2}{*}{$\begin{array}{c}\begin{array}{c}\text { Perpignan, } \\
\text { France }\end{array} \\
\text { CBUL } \\
41.326\end{array}$} & \multirow{2}{*}{$\begin{array}{c}\begin{array}{c}\text { France } \\
\text { (locality } \\
\text { unknown) }\end{array} \\
\begin{array}{c}\text { NHMN, coll. } \\
\text { Bravard 12q, } \\
\text { cast }\end{array} \\
\end{array}$} & \multirow{2}{*}{ 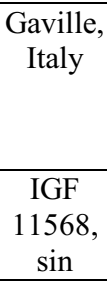 } \\
\hline & & & $\begin{array}{c}\text { PIN } \\
225-253\end{array}$ & $\begin{array}{c}\text { ZIN } \\
34996\end{array}$ & & & \\
\hline Length $\mathrm{c} 1-\mathrm{m} 3$ & & & ca109 & & 125.3 & 125.1 & 136.0 \\
\hline Length $\mathrm{c} 1-\mathrm{m} 2$ & & ca83.9 & ca94 & & & & \\
\hline Length alvp4-m3 & & & 66.3 & & 66.1 & 76.1 & 76.5 \\
\hline Length alvp4-m2 & & 49.2 & 52.9 & & & & \\
\hline Length $\mathrm{m} 1-\mathrm{m} 3$ & 53.2 & & ca56 & & 54.7 & 63.1 & 64.5 \\
\hline Length $\mathrm{m} 1-\mathrm{m} 2$ & & 38.2 & ca42 & & & & \\
\hline Height behind $\mathrm{ml}$ & & 29.9 & 37.3 & & & 36.7 & 49.5 \\
\hline Height behind $\mathrm{p} 4$ & 39.5 & & & & 42.6 & 42.4 & 49.0 \\
\hline Height behind $\mathrm{p} 2$ & & 33.6 & 35.7 & 32.8 & & & \\
\hline \multicolumn{8}{|l|}{ Teeth } \\
\hline c1 L & 14.5 & ca17.1 & & 18.7 & 26.3 & 23.5 & 25.0 \\
\hline $\mathrm{c} 1 \mathrm{~W}$ & 12.6 & ca10.0 & & 11.5 & 13.8 & 13.8 & 14.5 \\
\hline p3 L & & & 7.6 & & 7.0 & & \\
\hline p3 W & & & 4.2 & & 4.5 & & \\
\hline $\mathrm{p} 4 \mathrm{~L}$ & & & & 11.9 & 12.1 & 13.3 & 11.4 \\
\hline $\mathrm{p} 4 \mathrm{~W}$ & & & & 6.1 & 6.9 & 7.7 & 6.9 \\
\hline $\mathrm{m} 1 \mathrm{~L}$ & 20.9 & 20.4 & ca22.1 & 21.0 & 20.4 & 23.6 & 25.1 \\
\hline $\mathrm{m} 1 \mathrm{~W}$ & 9.4 & 9.4 & 9.3 & 9.7 & 9.1 & 12.5 & 11.5 \\
\hline $\mathrm{m} 2 \mathrm{~L}$ & 17.9 & 17.9 & 20.0 & & 20.0 & 22.5 & 22.7 \\
\hline $\mathrm{m} 2 \mathrm{~W}$ & 10.6 & 11.3 & 11.2 & & 11.8 & 15.5 & 13.8 \\
\hline m3 L & 14.5 & & 14.3 & & 15.1 & 16.3 & \\
\hline $\mathrm{m} 3 \mathrm{~W}$ & 11.6 & & 11.1 & & 11.6 & 13.5 & \\
\hline
\end{tabular}

cheek teeth (Tabs. 1-3). The increasing of $\mathrm{m} 2$ is notably expressed: in the specimens from the Early Ruscinian of Europe (Baraolt-Căpeni, Moiseevka, MN14) the length of $\mathrm{m} 2$ is significantly smaller than that of $\mathrm{m} 1$. However $\mathrm{m} 1$ and $\mathrm{m} 2$ from the Late Ruscinian specimens (Perpignan, Kosyakino, MN15) are approximately equal in length. The lower jaw from the Late Villányian (Gaville, MN16) has $\mathrm{m} 1$ which is significantly longer than $\mathrm{m} 2$. Moreover, tooth sizes are notably larger than those in the bears from the Early Ruscinian. Length ratio of $\mathrm{m} 1 / \mathrm{m} 2$ of $U$. minimus yinanensis from China (Dongxiang, Yinan) are similar to those from the Early Ruscinian, although the geological age of the Chinese taxon is more late (it is equal to MN16-17; Qiu et al., 2009). In recent $U$. thibetanus $\mathrm{m} 1$ and $\mathrm{m} 2$ are approximately equal in length. It may be hypothesized that Asian black bear diverged from the Late Ruscinian ursids. This proposal was confirmed by the results of the molecular studies (Talbot \& Shields, 1996) and paleontological data (Baryshnikov \& Zakharov, 2013).

All examined specimens have similar proportions of $\mathrm{m} 1$. Height of the paraconid and metaconid is approximately equal (in the ancestral Miocene Ursavus primaevus the metaconid is higher than paraconid). The dimensions of these cusps changed during the evolution, therefore in the recent Ursus thibetanus the paraconid is pronouncedly higher than metaconid. The metaconid, in general, is single-cusped (Baraolt-Căpeni, Perpignan, Včeláre). However, many specimens from Odessa Catacombs and Gaville have premetaconid (Roshchin, 1956; Berzi, 1966; Ryziewicz, 1969; Vekua, 1972). Even in the same series of specimens this feature may be rather variable (Kosyakino, Węże 1). Recent Asian black bear (U. thibetanus) has smaller doublecusped metaconid connected to protoconid (in some cases, it can be formed only by a single cusp of the metaconid).

Evolutionary changes of $\mathrm{m} 1$ morphology also include the increasing of the talonid size, which is enlarged transversally in the latest representatives of the species (Tab. 1). In Ursus minimus the talonid and trigonid are separated by the large transversal groove facing the lingual side of the crown. The same peculiarities are typical for recent $U$. thibetanus. This groove may be of exposed type (ZIN 34996, Kosyakino) or closed type, in the latter the groove is overlapped by enamel cuspid close to the tooth border (the specimen from Moiseevka). The hypoconid of all described specimens is large, its inner lobe is not separated. The entoconid morphology in described specimens is variable. The entoconid of the most specimens (BaraoltCăpeni, Węże 1, Perpignan, Včeláre, Odessa Cata- 
Table 2. Measurements (mm) of lower molar $\mathrm{m} 1$ of Ursus minimus.

\begin{tabular}{|c|c|c|c|c|c|c|}
\hline Localities & Museum number & $\begin{array}{l}\text { Greatest } \\
\text { length }\end{array}$ & $\begin{array}{l}\text { Buccal } \\
\text { length of } \\
\text { trigonid }\end{array}$ & $\begin{array}{l}\text { Width } \\
\text { of trigonid }\end{array}$ & $\begin{array}{l}\text { Width } \\
\text { of } \\
\text { talonid }\end{array}$ & $\begin{array}{l}\text { Width of } \\
\text { constric- } \\
\text { tion }\end{array}$ \\
\hline \multicolumn{7}{|c|}{ U. minimus boeckhi } \\
\hline $\begin{array}{l}\text { Baraolt-Căpeni, Romania } \\
\text { (MN14) }\end{array}$ & CBUL 3302, cast & 20.9 & ca14.4 & 9.0 & 9.4 & 8.7 \\
\hline $\begin{array}{l}\text { Moiseevka, Kazakhstan } \\
\text { (early MN15) }\end{array}$ & PIN 5332-1 & 20.4 & 13.2 & 7.9 & 9.4 & 8.1 \\
\hline \multicolumn{7}{|c|}{ U. minimus minimus } \\
\hline \multirow{2}{*}{$\begin{array}{l}\text { Kosyakino, Russia } \\
\text { (MN15) }\end{array}$} & PIN 225-253 & ca22.1 & - & 7.6 & 9.3 & 7.8 \\
\hline & ZIN 34996 & 21.0 & 14.1 & 8.0 & 9.7 & 8.0 \\
\hline $\begin{array}{l}\text { Perpignan, France } \\
\text { (MN15) }\end{array}$ & CBUL 41.326 & 20.4 & 13.0 & 8.0 & 9.1 & 7.7 \\
\hline \multirow{5}{*}{ Węże 1, Poland (MN15) } & ISEA MF/833/67/5 & 21.0 & 13.0 & 7.5 & 8.8 & 7.6 \\
\hline & ISEA MF/833/67/9 & 22.8 & 14.3 & 8.5 & 10.9 & 9.4 \\
\hline & ISEA MF/833/67/13 & 21.2 & 12.9 & 7.8 & 9.1 & 7.5 \\
\hline & ISEA MF/833/67/15 & 19.2 & 12.3 & 7.7 & 8.5 & 6.8 \\
\hline & ISEA MF/833/67/17 & 19.4 & 13.1 & 8.1 & 9.0 & 8.3 \\
\hline Včeláre, Slovakia (MN16) & SNMB Z26702 & 21.4 & 14.5 & 8.5 & 9.3 & 8.3 \\
\hline France (locality unknown) & $\begin{array}{c}\text { NHMN, coll. Bravard } \\
12 \mathrm{q} \text {, cast }\end{array}$ & 23.6 & 14.4 & 9.8 & 12.5 & 10.2 \\
\hline \multirow[t]{2}{*}{ Gaville, Italy (MN16) } & IGF $11568, \sin$ & 25.1 & 15.2 & 10.4 & 11.5 & 9.2 \\
\hline & IGF 11568, dex & 24.8 & 16.6 & 9.7 & 10.3 & 8.9 \\
\hline
\end{tabular}

Table 3. Measurements (mm) of lower molar m2 of Ursus minimus.

\begin{tabular}{|c|c|c|c|c|c|c|}
\hline Localities & Museum number & $\begin{array}{l}\text { Greatest } \\
\text { length }\end{array}$ & $\begin{array}{l}\text { Buccal } \\
\text { length of } \\
\text { trigonid }\end{array}$ & $\begin{array}{l}\text { Lingual } \\
\text { length of } \\
\text { trigonid }\end{array}$ & $\begin{array}{l}\text { Width } \\
\text { of } \\
\text { trigonid }\end{array}$ & $\begin{array}{l}\text { Width } \\
\text { of } \\
\text { talonid }\end{array}$ \\
\hline \multicolumn{7}{|c|}{ U. minimus boeckhi } \\
\hline $\begin{array}{l}\text { Baraolt-Căpeni, Romania } \\
\text { (MN14) }\end{array}$ & CBUL 3302, cast & 17.9 & 12.0 & - & 10.6 & 10.5 \\
\hline $\begin{array}{l}\text { Moiseevka, Kazakhstan } \\
\text { (MN14) }\end{array}$ & PIN 5332-1 & 17.9 & 11.2 & 9.7 & 11.3 & 10.5 \\
\hline \multicolumn{7}{|c|}{ U. minimus minimus } \\
\hline Kosyakino, Russia (MN15) & PIN 225-253 & 20.0 & 12.6 & 10.0 & 11.0 & 11.2 \\
\hline \multirow{4}{*}{ Węże 1, Poland (MN15) } & ISEA MF/833/67/6 & 20.4 & 12.4 & 10.4 & 11.0 & 11.5 \\
\hline & ISEA MF/833/67/7 & 21.2 & 12.3 & 11.5 & 12.3 & 11.8 \\
\hline & ISEA MF/833/67/8 & 20.6 & 13.1 & 11.8 & 11.2 & 11.3 \\
\hline & ISEA MF/833/67/21 & 20.5 & 11.9 & 11.1 & 10.9 & 11.6 \\
\hline Perpignan, France (MN15) & CBUL 41.326 & 20.7 & 11.6 & 10.5 & 11.6 & 11.8 \\
\hline France (locality unknown) & $\begin{array}{c}\text { NHMN, coll. } \\
\text { Bravard } 12 \mathrm{q}, \text { cast }\end{array}$ & 22.5 & 14.8 & 12.5 & 15.5 & 15.0 \\
\hline \multirow[t]{2}{*}{ Gaville, Italy (MN16) } & IGF $11568, \sin$ & 22.7 & 13.2 & 12.5 & 12.8 & 13.8 \\
\hline & IGF $11568, \mathrm{dex}$ & 22.4 & 13.1 & 12.8 & 11.8 & 12.7 \\
\hline
\end{tabular}

combs, Gaville, and PIN No.225/253, Kosyakino) is single-cusped and displaced to the caudal side of the crown. Sometimes there is an accessory cuspid, located anteriorly from the entoconid (ZIN 34996, Kosyakino). The entoconid may be ridge-shaped or double-cusped (Moiseevka specimen). It is necessary to note that the entoconid of Ursavus primaevus is double-cusped (Baryshnikov, 2007: Fig. 59). In recent Ursus thibetanus, as a rule, the entoconid is singe-cusped.

The structure of the metaconid of $\mathrm{m} 2$ is rather different in $U$. minimus. The metaconid is single-cusped and nearly equal in height to protoconid (in the specimen from Moiseevka locality). Frequently the metaconid is considerably higher than protoconid (BaraoltCăpeni, Kosyakino, Perpignan, Odessa Catacombs). Sometimes there are accessory cuspids, located anteriorly and posteriorly from the main cusp of metaconid (Węże 1, Odessa Catacombs, Kvabebi). The entoconid is regularly double-cusped and shifted backwards (in CBUL 3302 from Baraolt-Căpeni it is single-cusped). It looks like weakly serrated ridge with more expressed posterior cuspid (Moiseevka, Perpignan). The ento- 
conid of $\mathrm{m} 2$ is double-cusped in recent Ursus thibetanus, similar to the aforementioned specimen of U. minimus.

\section{Conclusion}

This study takes the opportunity to determinate the main trends of teeth morphological changes of the $U r$ sus minimus. The specimens of this species from the Early Ruscinian (Baróth-Köpec, Moiseevka) are characterized by archaic tooth morphology and small size. The members of $U$. minimus from the Late Ruscinian are characterized by larger size of the teeth in comparison to the Early Ruscinian ursids. All specimens of $U$. minimus from the Late Ruscinian are very close to each other in tooth sizes and their morphology (Kosyakino, Węże 1, Perpignan and possible Odessa Catacombs). The largest tooth sizes are correlated with maximum number of structures at the masticatory surface in the $U$. minimus specimens from the Early Villányian (MN16; Gaville and Kvabebi localities).

Despite considerable intraspecific variability of the tooth features in bears, studied specimens of $U$. mini$m u s$ are morphologically similar. All variations observed are typical for intraspecific variability in bears and other omnivorous carnivores. Therefore there are no solid reasons for subdivision of Ursus minimus into a different species.

The detection of tendencies of the tooth apparatus evolution in $U$. minimus was made on the basis of European fossils material. However, the tendencies and peculiarities of the evolutionary process in the Asiatic part of the specific range stay indistinctive. The specimens of $U$. minimus from Caucasus (Kosyakino, Kvabebi) correspond to the European trends. The specimen from Kazakhstan (Moiseevka) possesses some peculiarities in morphology of $\mathrm{m} 1$ talonid in contrast to the specimens from Europe. The available specimens of $U$. minimus from China (Dongxiang, Yinan) are characterized by retaining of plesiomorphic features (small tooth sizes and the $\mathrm{m} 1 / \mathrm{m} 2$ length ratio; Qiu et al., 2009).

Thus $U$. minimus is characterized by geographic variability in its large specific range which covered the most part of Eurasia. The geographic variability of the species was well expressed during both the Early Pliocene ( $U . m$. boeckhi in Europe and $U . m$. ssp. in Kazakhstan) and the Late Pliocene (U. m. minimus in Europe and U. m. yinanensis in China).

ACKNOWLEDGEMENTS. The material for examination and comparison has been provided by Dr. V. Eisenmann (NHMN), Prof. C. Guérin (CBUL), Dr. E. Crégut-Bonnoure (RMA), Dr. L. Rook (IGF), Prof. R. Ziegler (SMNS), Dr. H. Lutz (NMM), Prof. A. Nadachowski, Dr. P. Wojtal and Dr. G. Lipecki (ISEA), Dr. M. Sabol and Dr. A. Durisova (SNMB). Dr. J. Wagner (Prague) and G. Nazimbetova (Almaty) gave us valuable advices in preparing the paper and Dr. S. Baryshnikova (ZIN) assisted us in this study.

\section{References}

Alberdi M.T., Azanza B., Cerdeño E. \& Prado J.L. 1997. Similarity relationship between mammal faunas and biochronology from latest Miocene to Pleistocene in western Mediterranean area // Eclogae Geologicae Helvetiae. T.90. P.115-132.

Argiropulo A.I. 1939. [Remains of beaver Amblycastor caucasicus sp. n. from Ciscaucasia Pliocene] // Doklady Akademii Nauk SSSR. Vol.25. No.7. P.638-640 [in Russian].

Argiropulo A.I. 1940. [Review of Tertiary rodent findings from USSR and adjoining territory of Asia] // Priroda. No.12. P.74-82 [in Russian].

Averianov A.O. \& Tesakov A.S. 1998. [The Lagomorpha (Mammalia) from the Early Pliocene Kosyakino locality of the Northern Caucasus] // Paleontologicheskii Zhurnal. No.3. P.91-96 [in Russian].

Baryshnikov G.F. 2003. Late Miocene Indarctos punjabiensis atticus (Carnivora, Ursidae) in Ukraine with survey of Indarctos records from the former USSR // Russian Journal of Theriology. Vol.1 (for 2002). No.2. P.83-89.

Baryshnikov G.F. 2007. [Mammals. The Bears Family (Ursidae)] // Fauna of Russia and Neighbouring Countries. N.ser. 147. Nauka: Sankt-Peterburg. 542 p. [in Russian].

Baryshnikov G.F. \& Zakharov D.S. 2013. Early Pliocene Ursus thibetanus (Mammalia, Carnivora) from Priozernoe locality in the Dniester basin (Moldova Republic) // Proceedings of the Zoological Institute RAS. Vol.317. No.1. P.3-10.

Beliaeva E.I. 1940. [New Upper Tertiary mammal fauna from Northern Caucasus] // Priroda. No.2. P.82 [in Russian].

Beliaeva E.I. 1944. [New material by Upper Tertiary mammals from Northern Caucasus] // Priroda. No.3. P.76-77 [in Russian].

Berzi A. 1966. L'orso di Gaville nel Valdarno Superiore // Palaeontographia Italica. Vol.40 (for 1965). P.19-32 + VI-XIX Tav.

Croizet A. \& Jobert A. 1828. Recherches Sur Les Ossemens Fossils du Département du Puy-de-Dôme. Paris: Chez les Princip. Library. 224 p.

Depéret Ch. 1890. Les animaux pliocènes du Roussillon // Mémoires de la Société Géologique de France. Paléontologie. Mém. 3. P.1-88.

Dubrovo I.A. \& Kapelist K.V. 1979. [Catalogus of Tertiary Vertebrate Localities in Ukraine]. Moskva: Nauka. 160 p. [in Russian].

Fejfar O. \& Heinrich W.-D. 1990. Proposed biochronical division of the European continental Neogene and Quaternary based on muroid rodents (Rodentia, Mammalia) // Fejfar O. \& Heinrich W.-D. (eds.). International Symposium "Evolution, Phylogeny and Biostratigraphy of Arvicolids (Rodentia, Mammalia)". München: Verlag Dr. Friedrich Pfeil. P.115-124.

Fejfar O., Heinrich W.-D. \& Lindsay E.H. 1998. Updating the Neogene rodent biochronology in Europe // Mededelingen Nederlands Instituut voor Toegepaste Geowetenschappen TNO. Vol.60. P.533-554.

Jánossy D. 1978. Larger mammals from the lowermost Pleistocene fauna Osztramos, Loc. 7 (Hungary) // Annales 
Historico-Naturales Musei Nationalis Hungarici. Vol.70. P.69-79.

Kelly Th. 1994. Two Pliocene (Blancan) vertebrate faunas from Douglas County, Nevada // PaleoBios. Vol.16. No.1. P.1-23.

Korotkevich M.L. 1967. [Large mammals from the Pliocene layers of Kuèurgan River] // Mesto i Znachenie Iskopaemykh Mlekopitayushchikh Moldavii v Kainozoe SSSR. Kishinev: Shtiintsa. P.77-84 [in Russian].

Kostenko N.N. 1963. [Stratigraphical Foundation of Anthropogene of Kazakhstan]. Alma-Ata: Izdatelstvo Akademii Nauk KazSSR. 74 p. [in Russian].

Krause J., Unger T., Noçon A., Malaspinas A.-S., Kolokotronis S.-O., Stiller M., Soibelzon L., Spriggs H., Dear P.H., Briggs A.W., Bray S.C.E., O’Brien S.J., Rabeder G., Matheus P., Cooper A., Slatkin M., Pääbo S. \& Hofreiter M. 2008. Mitochondrial genomes reveal an explosive radiation of extinct and extant bears near the Miocene-Pliocene boundary // BMC Evolutionary Biology. Vol.8: 220. DOI 10.1186/1471-2148-8-220.

Kurtén B. \& Anderson E. 1980. Pleistocene Mammals of North America. New York: Columbia University Press. $443 \mathrm{p}$.

Li Y. 1993. On a new species of Pliocene Ursus (Carnivora: Ursidae) from Yinan, Shandong Province // Vertebrata Palasiatica. Vol.31. No.1. P.44-60 + Pl.I-II.

Lopatin A.V., Tesakov A.S. \& Titov V.V. 2003. Late Miocene - early Pliocene porcupines (Rodentia, Hystricidae) from south European Russia // Russian Journal of Theriology. Vol.2. No.1. P.26-32.

Maier von Mayerfels S. 1929. Zur Stammesgeschichte der europäischen Bären // Neues Jahrbuch für Mineralogie, Geologie und Paläontologie, Beilagen-Band 72. S.325332.

Mazza P. \& Rustioni M. 1994. On the phylogeny of Eurasian bears // Palaeontographica. Abt.A. Vol.230. P.1-38.

Mein P. 1990. Updating of MN zones // Lindsay E.H., Fahlbusch V. \& Mein P. (eds.). European Neogene Mammal Chronology. New York: Plenium Press. P.73-90.

Montoya P., Ginsburg L., Alberdi M.T., Van Der Made J., Morales J. \& Soria M.D. 2006. Fossil large mammals from the early Pliocene locality of Alcoy (Spain) and their importance in biostratigraphy // Geodiversitas. T.28. No.1. P.137-173.

Morlo M. \& Kundrát M. 2001. The first carnivoran fauna from the Ruscinium (Early Pliocene, MN 15) of Germany // Paläontologische Zeitschrift. Bd.75. No.2. P.163187.

Nikiforova K.V. 1953. [Geomorphology and geological situation in Irtysh River depression] // Trudy Geologicheskogo Instituta Akademii Nauk SSSR. T.141. P.333 [in Russian].

Pagés M., Calvignac S., Klein C., Paris M., Hughes S. \& Hänni C. 2008. Combined analysis of fourteen nuclear genes refines the Ursidae phylogeny // Molecular Phylogenetics and Evolution. Vol.47. P.73-83.

Qiu Z.-X., Deng T. \& Wang B.-Y. 2009. First ursine bear material from Dongxiang, Gansu - Addition to the Longdan mammalian fauna // Vertebrata PalAsiatica. Vol.47. No.4. P.245-264.
Roshchin A.D. 1956. [Upper Pliocene fauna of south part of Ukraine] // Naukovye Zapiski Geographicheskogo Fakulteta Odesskogo Pedagogicheskogo Instituta. Ò.14. P.33-83 + V Tabls [in Ukrainian].

Ryziewicz Z. 1969. Badania nad niedŸ wiedziami plioceñski$\mathrm{mi} / /$ Acta Palaeontologica Polonica. Vol.14. No.2. P.199$243+$ VI Pls. [with English and Russian summary].

Sabol M., Holec P. \& Wagner J. 2008. Late Pliocene Carnivores from Vèeláre 2 (Southeastern Slovakia) // Paleontological Journal. Vol.42. P.531-543.

Schlosser M. 1899. Parailurus anglicus und Ursus boeckhi aus den Ligniten von Baróth-Köpecz // Mittheilungen aus dem Jahrbuche der Königlich Ungarische Geologischen Anstalt. Bd.13. S.67-95 + X-XIII Pls.

Soria D. \& Morales J. 1976. Hallazgo de un Ursido en el yacimiento de Layna (Soria) // Trabajos Sobre Neogeno Cuaternario. T.5. P.129-140.

Sotnikova M.V. \& Kalmykov N.P. 1991. [Pliocene associate of carnivore mammals at locality Udunga (western Transbaikalia)] // Vangengeim E.A. (ed.). Paleogeografiya i Biostratigrafiya Pliotsena i Antropogena. Moskva: Geologicheskii Institut Akademii Nauk SSSR. P.146-160 [in Russian].

Sotnikova M.V. 2008. Carnivora assemblages of the Ruscinian - Early Villafranchian transition: Eastern Europe (Ukraine) and Russia (Transbaikalia) - similarity and distinctions // Abstracts of 6th Meeting of the European Association of Vertebrate Palaeontologists, 30 June -5 July, 2008. Spišská Nová Ves, Slovak Republic. P.8587.

Sotnikova M. \& Rook L. 2010. Dispersal of the Canini (Mammalia, Canidae: Caninae) across Eurasia during the Late Miocene to Early Pleistocene // Quaternary International. Vol.212. P.86-97.

Spassov N. 2003. The Plio-Pleistocene vertebrate fauna in South-Eastern Europe and the megafaunal migratory waves from the east to Europe // Revue de Paléobiologie, Genève. Vol.22. No.1. P.197-229.

Talbot S.L. \& Shields G.F. 1996. A phylogeny of the bears (Ursidae) inferred from complete sequences of three mitochondrial genes // Molecular Phylogenetics and Evolution. Vol.5. P.567-575.

Tedford R. \& Harington R. 2003. An Arctic mammal fauna from the Early Pliocene of North America // Nature. Vol.425. P.388-390.

Teilhard de Chardin P. 1940. The fossils from Locality 18 near Peking // Palaeontologica Sinica. Ser.C. Vol.9. P.1100.

Thenius E. 1947. Bemerkungen über fossile Ursiden (Mamm.) // Sitzungsberichte der Akademie der Wissenschaften in Wien, Mathematisch-Naturwissenschaftliche Klasse. Abt.1. Bd.156. Hf.3-4. S.201-208.

Vangengeim E.A. 1977. [Paleontological Foundation of the Anthropogene Stratigraphy of Northern Asia (On Mammals)]. Moskva: Nauka. 170 p. [in Russian].

Vangengeim E.A., Pevzner M.A. \& Tesakov A.S. 2005. [Age of boundary and position in magnitochronology scale of Ruscinian and lower Villafranchian] // Stratigrafiya. Geologicheskaya Korrelyatsiya. Vol.13. No.5. P.78-95 [in Russian]. 
Vekua A.K. 1972. [Akchagyl Vertebrates of Kvabebi Locality]. Moskva: Nauka. 351 p. + XXXVI Tabs. [in Russian].

Vereshchagin N.K. 1959. [Mammals of Caucasus. History of Fauna Origin]. Moskva-Leningrad: Izdatelstvo Akademii Nauk SSSR. 704 p. [in Russian].

Vislobokova I.A. 1996. The Podpusk-Lebyazh'e mammalian faunas assemblage, Western Siberia // Palaeontographia Italica. Vol.83. P.1-23.

Vislobokova I., Sotnikova M. \& Dodonov A. 2001. Late Miocene-Pliocene mammalian faunas of Russia and neighbouring countries // Bollettino della Società Paleontologica Italiana. Vol.40. No.2. P.307-313.

Wagner J. 2010. A list of craniodental material of Pliocene ursids (genus Ursus) in the collection of Naturhistorisches Museum Basel // Scientific Annals, School of Geology Aristotle University of Thessaloniki. Special Vol.98. P.127-139.

Wagner J. 2010. Pliocene to early Middle Pleistocene ursine bears in Europe: a taxonomic overview // Journal of the
National Museum (Prague), Natural History Series. Vol.179. No.20. P.197-215.

Wagner J., Čermak S. \& Horaèek I. 2012. The presence of Ursus ex gr. minimus-thibetanus in the Late Villanyian and its position among the Pliocene and Pleistocene black bears Europe // Quaternaire, Hors Ser. Vol.4 (for 2011). P.39-58.

Zazhigin V.S. 1980. [Late Pliocene and Anthropogene rodents of the south of Western Siberia] // Trudy Geologicheskogo Instituta Akademii Nauk SSSR. T.339. P.1156 [in Russian].

Zdansky O. 1927. Weitere Bemerkungen über fossile Carnivoren und Cerviden aus China // Palaeontologica Sinica. Ser. C. Vol.4. Fasc.4. P.1-30 + II Taf.

Zinova R.A. 1982. [Pliocene of North Part of Central Kazakhstan]. Minsk: Nauka i Tekhnika. 149 p. [in Russian].

Zykin V.S., Zykina V.S. \& Zazhigin V.S. 2007. [Problems of difference and correlation of Pliocene and Quaternary sediments of south part of Western Siberia] // Arkheologiya, Etnografiya i Antropologiya Evrazii. No.2. P. 24-40 [in Russian]. 